\title{
An Overview of Early Anthrax Outbreaks in Northern Canada: Field Reports of the Health of Animals Branch, Agriculture Canada, 1962-71
}

\author{
D.C. DRAGON ${ }^{1}$ and B.T. ELKIN ${ }^{2}$
}

(Received 9 May 2000; accepted in revised form 26 July 2000)

\begin{abstract}
Between 1962 and 1971, six outbreaks of anthrax occurred in the bison herds of the Northwest Territories and northern Alberta. In response, the federal Health of Animals Branch dispatched staff veterinarians to oversee carcass disposal operations and later to take part in bison depopulation and vaccination programs. Recently, a collection of documents from that agency concerning the outbreaks was discovered in the federal archives. The collection includes field reports from the veterinarians that provide valuable, detailed, first-person accounts of the outbreaks and later programs, information which has generally been lacking in the published literature. The reports identify at least 1102 bison that died of anthrax during the six outbreaks, dozens more than reported previously. They also indicate that the disease spread into Wood Buffalo National Park in 1963, rather than in 1964, as reported previously. A minimum of 598 healthy bison were also killed in depopulation programs aimed at preventing the spread of anthrax into the Park, even though anthrax carcasses had already been discovered within the Park and the targeted regions would be repopulated within weeks. Coverage and revaccination rates were low throughout the vaccination program, and a further 828 bison died during the vaccine roundups.
\end{abstract}

Key words: anthrax, bison, disease, Northwest Territories, Wood Buffalo National Park

RÉSUMÉ. Entre 1962 et 1971, six épidémies d'anthrax ont eu lieu dans les troupeaux de bisons des Territoires du Nord-Ouest et de l'Alberta septentrional. La Direction générale de l'hygiène vétérinaire du gouvernement fédéral réagit en dépêchant ses vétérinaires attitrés pour superviser les opérations d'élimination des cadavres et pour participer ensuite aux programmes d'abattage intégral et de vaccination. On a découvert récemment dans les archives fédérales un ensemble de documents provenant de cette agence concernant les épidémies. Cette collection comprend des rapports d'enquête rédigés par les vétérinaires, qui offrent des récits à la première personne, intéressants et détaillés, sur les épidémies d'anthrax et les mesures subséquentes, information qui, dans l'ensemble, n'apparaît pas dans les publications. Les rapports indiquent que, durant les six épidémies d'anthrax, au moins 1102 bisons sont morts, ce qui représente plusieurs dizaines de plus que ce qui a déjà été rapporté. Ils révèlent également que la maladie s'est répandue dans le parc national Wood Buffalo en 1963 plutôt qu'en 1964, comme on l'a rapporté précédemment. Un minimum de 598 bisons sains ont en outre été tués dans le cadre de l'abattage intégral visant à prévenir la propagation de l'anthrax dans le parc, en dépit du fait qu'on avait déjà découvert des animaux morts d'anthrax dans les limites du parc et que les régions ciblées devaient faire l'objet d'un repeuplement dans les semaines suivantes. Les taux de couverture et de revaccination étaient faibles durant toute la période couvrant le programme de vaccination, et 828 autres bisons périrent au cours des rassemblements de bêtes effectués en vue de la vaccination.

Mots clés: anthrax, bison, maladie, Territoires du Nord-Ouest, parc national Wood Buffalo

Traduit pour la revue Arctic par Nésida Loyer.

\section{INTRODUCTION}

During the summer of 1962, a large outbreak of anthrax occurred in the free-roaming bison (Bison bison) herds of the Hook Lake region, Northwest Territories, Canada (Fig. 1) (Novakowski et al., 1963). Over the next two summers, anthrax outbreaks continued in the region and spread, first across the Slave River to the Grand Detour region and later into the Park Central and Lake One regions of Wood Buffalo National Park (WBNP) (Choquette et al., 1972). Between 1962 and 1991, eight sporadic anthrax outbreaks of varying size occurred among the bison of these four regions, resulting in the death of over a thousand animals. As recently as 1993, a large-scale outbreak of the disease occurred in the bison herds of the Mackenzie Bison Sanctuary (MBS), located across Great Slave Lake from the previously affected areas (Gates et al., 1995).

${ }^{1}$ Department of Microbiology and Public Health, 2B3.08 Walter C. Mackenzie Health Sciences Centre, University of Alberta Hospitals, 8440 - 112 Street, Edmonton, Alberta T6G 2J2, Canada; present address: 5602 51A Avenue, Yellowknife, Northwest Territories X1A 1G4, Canada; dcdragon@internorth.com

${ }^{2}$ Department of Resources, Wildlife and Economic Development, Government of the Northwest Territories, 600,5102 - 50 Ave, Yellowknife, Northwest Territories X1A 3S8, Canada

(C) The Arctic Institute of North America 


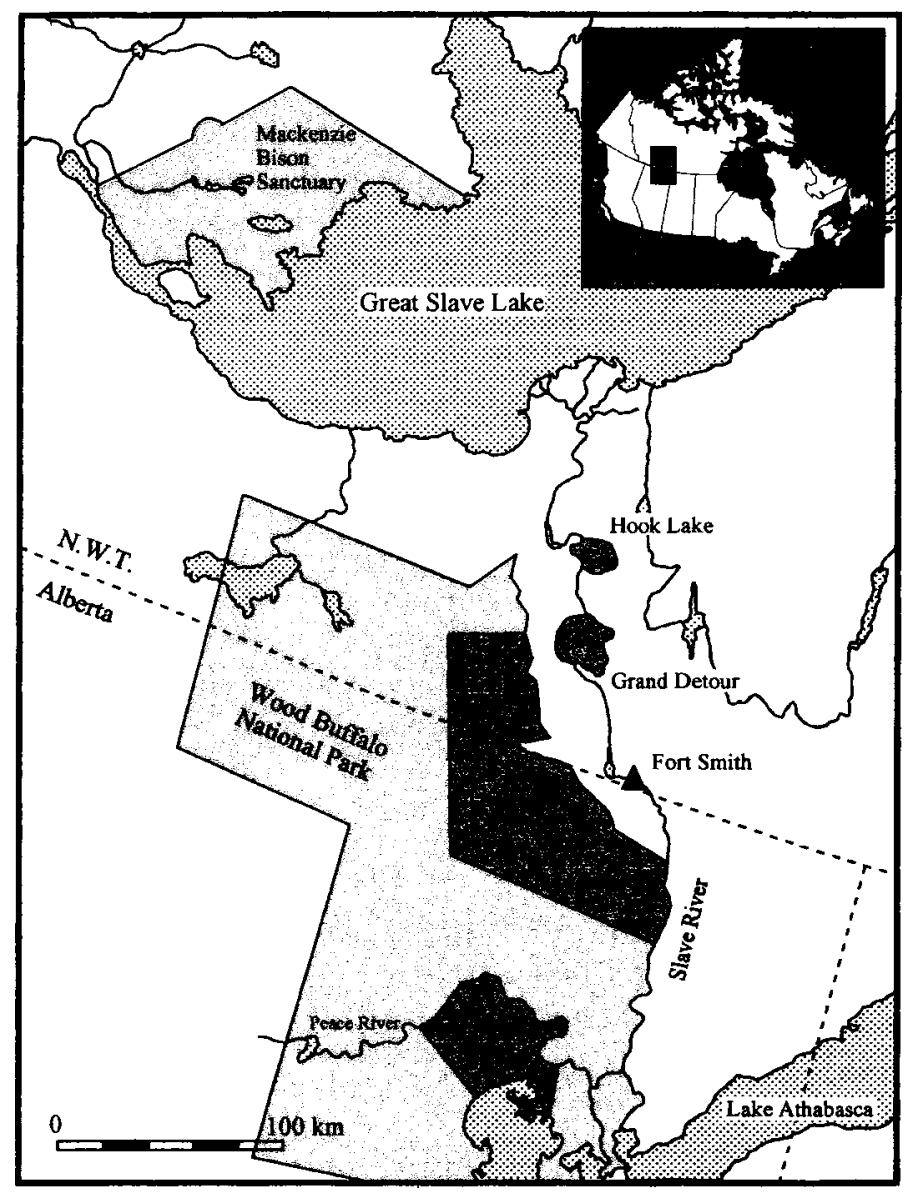

FIG. 1. Anthrax endemic regions in the Slave River Lowlands and Wood Buffalo National Park in northern Canada.

Because the outbreaks threatened recovery efforts for the endangered bison, and since the disease might possibly spread to inhabited regions and domestic livestock, the government initiated large-scale clean-up operations. The primary focus of the operations - to locate and dispose of carcasses as quickly as possible-is reflected in the published literature, which generally contains only cursory epidemiological details. Recently, a large collection of files from the Health of Animals Branch (HAB) concerning the department's response to the early anthrax outbreaks in northern Canada was discovered in the archives of the Canadian Food Inspection Agency. The files provide a wealth of previously unpublished observations on the early outbreaks from 1962 to 1971 . We summarize these novel data and place them within the framework of previously published literature to augment the known scientific literature on the disease and to provide greater detail on this period of history in northern Canada.

\section{HISTORICAL SOURCES}

Anthrax is a reportable disease under the Federal Health of Animals Act. During the period of the early northern anthrax outbreaks, the diagnosis and containment of the disease was the responsibility of Agriculture Canada. (Today the control of anthrax outbreaks falls under the jurisdiction of the Canadian Food Inspection Agency.) When the northern outbreaks occurred, the federal department sent a veterinarian from its Health of Animals Branch to collect samples for bacteriological confirmation of the disease and to supervise carcass disposal operations. Later, veterinarians were also sent north to help in other anthraxrelated operations, including large-scale anthrax vaccination campaigns and inspection of bison carcasses during a depopulation/harvest program in the Grand Detour region.

While in the field, the HAB veterinarians wrote daily reports on the progress of the operations, along with empirical observations on the weather, wildlife, and surrounding country. Copies of these reports, along with correspondence pertaining to the anthrax operations, were maintained in an anthrax file at the HAB regional office in Calgary, Alberta. Although most federal files are destroyed after 20 years, the anthrax documents were either misfiled or spared by an unknown party who realized their value. Their recent discovery allows present-day anthrax researchers to benefit from firsthand accounts of the early outbreaks. Fittingly, the HAB anthrax file has now been archived at the Glenbow Museum in Calgary.

\section{CHRONOLOGY AND MORTALITY}

\section{Original Outbreak at Hook Lake-1962}

The first anthrax outbreak at Hook Lake was discovered by chance. On 28 July 1962, a Canadian Wildlife Service (CWS) biologist, Dr. G. Kolensky, discovered 32 dead bison on two meadows while conducting a helicopter survey of bison habitat over the remote region (Novakowski et al., 1963). The animals had been dead only a few days, and he collected samples from several of the carcasses in an attempt to determine the cause of death. Over the next few days, Dr. Kolensky continued to survey the region and observed more bison carcasses. He began to map their locations. Between 28 July and 7 August, CWS personnel shot eight lethargic, morbid bison in the region and collected more samples. On 14 August, the federal Health of Animals Laboratory, by direct culture of Bacillus anthracis from the field samples collected, confirmed anthrax as the cause of death. Plans were immediately developed for a full-scale cleanup of infected carcasses in the region (MacEwan, 1995).

To better assess the situation, Dr. A.E. Lewis, HAB Alberta District Veterinarian, travelled to Fort Smith, and he and Dr. Kolensky surveyed the region by helicopter on 15 August. In a letter to his superiors, Dr. Lewis reported seeing nearly 100 carcasses spread over approximately $1500 \mathrm{~km}^{2}$, although most were concentrated on the two original meadows. Dr. Lewis also observed anthrax eschars on Dr. Kolensky's forearm. With no previous history of anthrax in the area to arouse suspicion, Dr. Kolensky had 
collected specimens from the first carcasses without gloves or other protective gear. A week later, he developed a general malaise, and carbuncles appeared on his forearm. Fortunately the local physician in Fort Smith, originally from England, apparently had experience with the disease and recognized the condition. Immediately he started treatment with the antibiotic tetracycline, which rapidly cleared Dr. Kolensky's malaise, although the black eschars typical of cutaneous anthrax were slower to resolve.

Logistical difficulties delayed the initiation of disposal operations. Supplies and equipment had to be transported by barge down the Slave River during the summer, and a quarantined base camp set up to ensure that living quarters remained uncontaminated by the hardy and infectious anthrax spores (Pyper and Willoughby, 1964). At its height, the disposal operation employed 40 men, five caterpillar tractors, two bombardier-type vehicles, and one muskeg tractor to dispose of the carcasses, all of which had to be barged into the area (MacEwan, 1995). Dr. Lewis did not remain at Hook Lake to supervise the operations, but instead assigned the duty to Dr. W.M. Norton. According to his field reports, Dr. Norton arrived at the base camp, a hastily converted abandoned sawmill, on 21 August, but disposals did not begin until 23 August, as the two tons of lime required had not yet arrived.

According to Novakowski et al. (1963), the team located approximately 120 carcasses between 28 July and 4 August 1962. Despite continued surveillance, no new deaths were observed from 4 to 15 August. A second wave of mortality was then reported, and 161 more carcasses were found between 15 and 21 August (Table 1). However, Dr. Norton's field report described a somewhat different sequence of events: he said that Dr. Kolensky had located only 156 carcasses by 21 August, and that aerial surveillance was not completed until 28 August, at which time 253 carcasses had been located and flagged. Included with the report was a copy of Dr. Kolensky's map with all 253 carcass locations. One can assume that Dr. Kolensky numbered the carcasses sequentially as he found them. Carcasses 1 to 156 were all located on the two meadows where the original 32 carcasses were found. Carcasses assigned numbers higher than 156 were generally found at a distance from these two main meadows. Instead of representing a second wave of bison mortalities, the delayed discovery of the last 97 carcasses may have been due to their being in previously unsearched areas. These 97 likely died at the same time as the rest of the infected bison: Dr. Norton repeatedly reported that no fresh bison carcasses were observed after 19 August, indicating that the epizootic had already ended by this date. The remaining carcasses noted by Novakowski et al. (1963) were later located by clean-up crews travelling through areas of thick vegetation, which had likely obscured aerial detection (Table 1). In the 1993 MBS outbreak, 55\% of the carcasses were located in forested or shrub-covered sites and were not visible from aircraft used to search for carcasses (Gates et al., 1995).

\section{Major Outbreak West of the Slave River-1963}

Anthrax was detected in the Hook Lake region again the following summer, and this time Dr. J.F. Gallivan of the HAB was dispatched to supervise clean-up operations. In his field report, Dr. Gallivan stated that a single carcass had been discovered in the region on 27 June by CWS biologists conducting an aerial survey of sandhill cranes. The biologists, who had been involved in clean-up operations the previous summer, immediately suspected anthrax. They were also familiar with Dr. Kolensky's encounter with the disease. Upon landing, they took the appropriate safety precautions before collecting biological specimens. These precautions were justified: $B$. anthracis was later isolated from the specimens.

Despite the possibility of another large anthrax outbreak, it was impossible to resurvey the Hook Lake area until 3 July, as all available aircraft were involved in

TABLE 1. Number of bison carcasses found during anthrax outbreaks in northern Canada.

\begin{tabular}{|c|c|c|c|c|c|c|}
\hline \multirow[t]{2}{*}{ Year } & \multicolumn{6}{|c|}{ Region Affected } \\
\hline & Hook Lake & Grand Detour & Park Central & Lake One & Mackenzie Bison Sanctuary & All Regions \\
\hline 1962 & 281 & - & - & - & - & $281^{1}$ \\
\hline 1963 & 15 & 242 & 47 & - & - & 304 \\
\hline 1964 & 44 & 259 & 49 & 11 & - & 363 \\
\hline 1967 & - & - & - & 120 & - & $120^{2}$ \\
\hline 1968 & - & - & - & 1 & - & $1^{2}$ \\
\hline 1971 & 33 & - & - & - & - & 33 \\
\hline 1978 & 12 & 27 & 40 & - & - & $79^{3}$ \\
\hline 1991 & - & - & 32 & - & - & $32^{4}$ \\
\hline 1993 & - & - & - & - & 172 & $172^{5}$ \\
\hline Total & 385 & 528 & 168 & 132 & 172 & 1385 \\
\hline
\end{tabular}

\footnotetext{
${ }^{1}$ Novakowski et al., 1963.

${ }^{2}$ Choquette et al., 1972.

${ }^{3}$ Broughton, 1987.

4 Broughton, 1992.

${ }^{5}$ Gates et al., 1995.
} 
fighting a large forest fire in WBNP. The surveillance flight on 3 July observed only five more carcasses, which were buried that same day along with the original carcass. Subsequent surveys were flown over the area daily, but by 17 July, only 12 carcasses had been detected. Surveillance flights over the area continued for several more weeks, yet only three more carcasses were found. The last one was located around 23 July.

If the second outbreak appeared anticlimactic compared to the first, it did not remain that way for long. Sometime between 18 and 29 July, a much larger outbreak was detected on the west side of the Slave River. The minutes of a meeting of the Anthrax Response Committee, which took place on 29 August in Edmonton, reported that 62 carcasses had been located in the Grand Detour region, and another 24 had been discovered in the northeast corner of WBNP within the Park Central region. This last point is interesting, as previous accounts of the outbreak had stated that carcasses were limited to the Hook Lake and Grand Detour areas (Choquette et al., 1972; Broughton, 1987). However, the discovery of carcasses within the Park boundaries is verified repeatedly in Dr. Gallivan's report and other correspondence. On 7 August, Dr. Gallivan stated that 117 carcasses had been found in the Grand Detour region and 37 in the Park Central region. Disposal operations were completed on 15 August: a total of 217 carcasses were buried west of the Slave River. In his 15 August entry, Dr. Gallivan stated:

The current anthrax outbreak [to the west of the Slave River] would appear to be terminated. I would estimate that all carcasses found with the exception of two had been dead for approximately one month. The two carcasses mentioned appeared to have been dead one week at the time of discovery.... The distance between the most northerly carcass and the one found furthest south in the Grand Detour area was approximately 80 miles. Fortyseven carcasses were found dead within the Park boundary.

A couple of weeks later, on 4 September, Dr. Gallivan reported that despite continued aerial surveys over the affected regions, no further carcasses had been detected. His final total of 217 carcasses buried west of the Slave River is well below the published figure of 269 (Choquette et al., 1972). However, in his 4 September report Dr. Gallivan went on to say that plans were in place to resurvey the regions in late autumn, after the leaves had fallen, and that any carcasses found would be burned. While there is no direct information on any additional carcasses being found in the fall survey, Dr. L.G. Gould of the HAB was in the region the following summer and reported that the final carcass total west of the river in the 1963 outbreak was 289.

\section{The Spread of Anthrax Continues-1964}

During the summer of 1964, regular anthrax surveillance flights were conducted over the previously affected regions. By the middle of July, a large outbreak was detected in the Grand Detour area, and a few additional carcasses were observed in the Hook Lake area. Fewer data are available in the HAB files on this and subsequent outbreaks, as WBNP personnel were now overseeing carcass disposal operations. By chance, Dr. Gallivan was in the area at the time to perform anthrax vaccinations on bison in WBNP, and he included information about this outbreak in his reports.

On 17 August, Dr. Gallivan reported that disposal operations were almost complete. He said that the outbreak had spread west across the entire Central Park region and south across the Peace River into the Lake One region. A total of 306 carcasses were located in the four regions: 44 at Hook Lake, 202 at Grand Detour, 49 at Park Central, and 11 at Lake One. The first deaths occurred in the Hook Lake and Grand Detour regions. The peak period of deaths was between 10 and 20 July, after which mortalities ended abruptly. No new carcasses were discovered after 22 July. Around this time carcasses were discovered in the Park Central regions, where deaths continued until around 4 August. No carcasses were reported in the Lake One region until 1 August, and the last of the deaths appeared to have occurred in this region, where the final carcasses were located around 10 August. As in the previous year, the affected areas were resurveyed in the fall. B.E. Olson, Superintendent of WBNP, reported in a letter:

In the Grand Detour area, we found 57 animals after the leaves shed off the trees, and these have all been limed, buried and/or burned. The same success has been achieved in the [Park Central region] ... as well as a few animals found around or adjacent to Lake One south of the Peace River.

Unfortunately, the number of carcasses found in the Park Central and Lake One regions during the fall cleanup was never recorded.

It is worth noting that the anthrax vaccination roundups, which Dr. Gallivan had originally come north to take part in during the summer of 1964, never took place. Initially, the large and expanding anthrax outbreak commanded everyone's attention, and later in the summer large-scale flooding of the bison ranges left the herds inaccessible. According to Dr. Gallivan, the end of the outbreak coincided with the arrival of heavy and continuous rains in all of the affected regions. The rains flooded all low-lying areas and made the terrain impassible for ground vehicles. The rain continued from mid-August through September, with two or three heavy showers occurring daily and leaving hundreds of $\mathrm{km}^{2}$ of prairie under water.

Water action has been demonstrated to transport anthrax spores passively in endemic regions of Kruger National Park, South Africa (De Vos, 1990) and has been implicated in spore transport in Canadian outbreaks (Heath and Brewitt, 1982; Dragon and Rennie, 1995). It is possible that the intensive flooding had a cleansing effect in the affected regions, flushing anthrax spores off low-lying 
prairies and dispersing heavy concentrations of spores. This may explain why, after three successive years of increases in both mortalities and their geographical range, the disease suddenly disappeared. No single cases or mass mortalities were observed during the summers of 1965 and 1966 despite favourable outbreak conditions and intensive surveillance. In subsequent outbreaks in the regions, the disease has generally remained limited in scope.

\section{Sporadic Outbreaks-1967 to 1971}

Choquette et al. (1972) stated that between 3 August and 7 September 1967, 120 bison died of anthrax in the Lake One region. A letter from Dr. Choquette of the CWS to Dr. Lewis confirms that the first carcasses were found on 3 August, but gives no indication of their condition or when the outbreak could have started. A copy of a specimen record sent south with blood samples indicated that the outbreak lasted until at least 20 August, on which date positive samples were collected from a bison dead less than 24 hours.

A single case of anthrax was confirmed in a dead bison in the Lake One region in 1968, and a small localized outbreak involving 31 carcasses was discovered in the Hook Lake region in 1971 (Choquette et al., 1972). Dr. L. Kindt of the HAB was in the area vaccinating bison at the time of the 1971 outbreak. Kindt reported that the first carcasses were found on 22 June, and the outbreak was estimated to have begun around 10 June. Fresh carcasses were found in the area until 6 July, when the outbreak appeared to have terminated. In addition to the official tally, two carcasses were found on 6 July, but their condition suggested they were winter kills and, though disposed of with the rest, they were not sampled or considered anthrax deaths. On the same day, however, searchers found the carcass of a bull bison that was in very poor shape: it showed signs of profuse, watery diarrhea and was still covered with a thick winter coat. It was believed this animal had also died of causes other than anthrax, but $B$. anthracis was subsequently isolated from anal and jugular swabs taken from the carcass.

Between 1962 and 1971, 1102 bison carcasses were found and disposed of during anthrax outbreaks in the Hook Lake, Grand Detour, Park Central, and Lake One regions (Table 1). This figure is a minimal estimate of the actual losses due to anthrax. Even though affected regions were resurveyed in autumn, after the leaves had fallen, undoubtedly carcasses were still missed in areas of heavy brush or had long since been dismembered by scavengers.

\section{PATHOLOGY AND SYMPTOMS IN BISON}

In bison, anthrax is usually acute and rapidly fatal. The classic, often repeated, appearance of morbid bison during anthrax outbreaks was first reported by Novakowski et al. (1963: 234):
The animals, head lowered, gaunt and drawn, feeding voraciously at times, were depressed and inordinately indifferent, whereas they should have been active and alert, as the outbreak occurred during the rut period. Most of the animals walked with difficulty, staggering at times, and exhibited a stiff-legged gait when running. Also, a swelling of the preputial and umbilical regions was noted in many animals.

There has been a temptation, especially during outbreaks, to assume that all inactive, indifferent, or limping bison are terminally ill with anthrax. However, these general traits are not prognostic indicators of a fatal anthrax infection. During outbreaks in northern Canada, a number of moribund bison were reported to have experienced a less acute form of the disease and recovered (Novakowski et al., 1963; Choquette et al., 1972; Gates et al., 1995). However, the number of animals recovering and their immunological status afterwards have never been determined. Stress due to environmental conditions associated with anthrax outbreaks, mechanical injury, or other diseases may also cause the bison to behave in an abnormal, "weakened" manner. Dr. Gallivan reported that two sick bison, one lame and the other weak, were shot during the 1963 outbreak. A post-mortem examination found both to be afflicted with tuberculosis, and neither exhibited any lesions suggestive of anthrax.

Acute anthrax appears to cause sudden death in bison, with no signs of struggle or flailing in the soil immediately surrounding the carcasses (Novakowski et al., 1963; Choquette et al., 1972; Gates et al., 1995). After death, the carcass bloats rapidly, causing the legs to splay in a "sawhorse" position. During the early outbreaks, carcasses were often found with a bloody discharge from the mouth or anus (Novakowski et al., 1963; Choquette et al., 1972). Occasionally, there was also a frothy white exudate from the mouth or nose. However, during the 1993 outbreak in the Mackenzie Bison Sanctuary, no bloody exudates from the natural body openings were observed that could not be traced to post-mortem scavenging, although one cadaver did have a frothy white discharge issuing from its nose (Gates et al., 1995). The discrepancy in reports of bloody discharge is one of the major differences between the early outbreaks around WBNP and the MBS outbreak, and its cause remains unknown.

The HAB files contain multiple references to bloody discharges from carcasses, indicating that the phenomenon was fairly common. Of particular interest is a 1963 field report from Dr. Gallivan, which demonstrated that the exudates were indeed a symptom of anthrax. While out surveying for carcasses, Dr. Gallivan came upon a yearling bull lying in the open prairie. The animal was very reluctant to move even with the helicopter hovering only a few feet above its head. The animal finally rose with great difficulty and slowly walked a short distance away. The aircraft landed, and Dr. Gallivan got out to observe the animal while the pilot flew back to camp to get a rifle. A 
few minutes after the helicopter left, the bull assumed a braced leg stance, began to sway, and suddenly toppled to the ground. As Dr. Gallivan watched, blood began to flow from the bull's nostrils. When the pilot returned with the rifle, the animal was shot, and blood samples were taken from which $B$. anthracis was later isolated.

Post-mortem examination of bison during anthrax outbreaks has been limited. During the 1962 outbreak, eight morbid bison were shot for specimen collection and necropsy (Novakowski et al., 1963). All eight exhibited subcutaneous edematous swellings, mostly in the underbelly area. In five of the animals, there were petechiae on the spleen, although the organ was not enlarged and was normal in consistency. In seven of the animals, the lymph nodes in the regions of swelling were hypertrophied and slightly hemorrhagic. The intestinal tracts of all the animals were congested, but the consistency of the feces was normal. In two of the animals, the rumen contained a large quantity of fluid. Other organs, such as the liver, pancreas, kidneys, and bladder, were congested. In all cases the blood clotted normally.

During the 1962 outbreak, Dr. Lewis performed an autopsy on a fresh carcass (Novakowski et al., 1963). The published account reported edematous swellings and a bloody discharge from the body openings. There was some degree of rigor mortis in the bloated animal. The spleen was twice its normal size and hemorrhagic, and the other organs were congested. The blood was dark and failed to clot. Among the HAB files are Dr. Lewis's notes on the post-mortem and the original specimen record, which expand on the truncated published account. Dr. Lewis estimated that the animal had died approximately 7 hours before examination and had not even had time to bloat completely. He observed a generalized septicemia, with hemorrhaging and yellow gelatinous exudates under the skin. The lymph glands were enlarged and hemorrhagic, and the spleen was twice its normal size and almost black in colour. The liver was congested, and there was a bloody discharge from the animal's anus. Bacillus anthracis was successfully isolated from spleen, liver, lymph, and gelatinous exudate specimens collected from the carcass.

A post-mortem was performed by CWS personnel on the first carcass found during the 1963 epizootic. The biologists noted that the cadaver was extremely bloated and had a bloody discharge issuing from its nose, but it had no significant edematous swelling. The blood of the carcass was dark and failed to coagulate. Upon necropsy some subcutaneous hemorrhaging was noted, and there were hemorrhagic petechiae on the liver. The spleen had ballooned to six times its normal size and was filled with uncoagulated blood. Bacillus anthracis was successfully isolated from ear and spleen specimens taken from the carcass.

Together, the limited necropsies indicate that bison infected with anthrax experience a terminal hemorrhagic septicemia. Generalized hemorrhage throughout the body is accompanied by subcutaneous gelatinous edema. The lymph nodes, especially near areas of edematous swelling, are hypertrophied and hemorrhagic. The blood is dark and often fails to clot. The spleen is enlarged and darkened, and the other viscera may be congested or display hemorrhagic petechiae. Carcasses bloat rapidly after death, and rigor mortis is often incomplete. There may be variable discharges of blood or white froth from the natural body openings, and serosanguinous fluid may accumulate in the digestive tract or abdominal cavity. Although these symptoms are suggestive of anthrax in bison, especially when accompanied by mass mortality, they are not diagnostic. Only bacteriological isolation of $B$. anthracis from the carcass is truly conclusive for the disease.

\section{OTHER SPECIES}

Although the northern anthrax outbreaks appeared to affect bison selectively, individual cases of anthrax have also been diagnosed in moose (Alces alces). Anthrax in moose was recorded only near the end of the largest epizootics in 1963, 1964, and 1993 (Choquette, 1970; Gates et al., 1995). This suggests that the disease "spilled over" into the moose population because of high levels of direct contact between moose and bison carcasses or largescale contamination of the local environment with spores from the numerous carcasses. Dr. Norton reported that clean-up crews found a single moose carcass during the 1962 epizootic. The animal's date of death was estimated to be around 12 August, near the end of the epizootic. Unfortunately, the state of decomposition precluded the collection of specimens for bacteriological investigation from this carcass, and its actual cause of death remained unknown.

Despite large-scale scavenging during the outbreaks, no cases of anthrax have been observed in northern carnivore and omnivore species. The northern outbreaks provide a very large, readily accessible source of contaminated food that attracts many scavenging species, but no evidence of disease has been found in these species, despite the fact that they literally gorge themselves on the carcasses. The carcass of a black bear (Ursus americanus) was found at Hook Lake near the end of the 1962 outbreak, but advanced decomposition precluded the collection of specimens for culture to determine whether anthrax had played a role in its death.

Anthrax spores have been isolated from the digestive tracts of ravens (Corvus corax) and herring gulls (Larus argentatus) shot while feeding on bison carcasses, but the birds did not show any signs of disease (Broughton, 1987; Gates et al., 1995). Because of these findings, intestinal carriage by avian scavengers has been implicated in the spread of $B$. anthracis spores between the northern epizootic regions (Choquette et al., 1972). There has been little sampling of non-avian scavengers for carriage of anthrax in northern Canada. Dr. Gallivan reported that anal and oral swabs were collected from the carcass of a black bear 
approximately 48 hours after it had been shot while feeding on a carcass during the 1971 epizootic, but the culture results were negative. During the same epizootic, oral and anal swabs were collected from a wolf that had been shot, but $B$. anthracis was not isolated. During the 1962 outbreak, Dr. Norton reported that a fox (Vulpes vulpes) showing no signs of fear and acting strangely had approached one of the clean-up crews. The workers feared the animal was rabid and shot it. The whole carcass was subsequently tested for both anthrax and rabies, but the laboratory was unable to isolate either microbe. The fox had undoubtedly been feeding on bison carcasses and may have been carrying spores on its fur or in its intestinal tract, but diagnostic testing was done only on the blood and spleen. The role of scavengers as mechanical vectors of anthrax spores during epizootics remains unclear.

Biting insects have also been implicated in the transmission of anthrax in northern Canada (Pyper and Willoughby, 1964; Cousineau and McClenaghan, 1965; Broughton, 1992). In their correspondence, Drs. Lewis, Norton, and McClenaghan all felt that while insects were not responsible for the initiation of the outbreaks, they might have been involved in their spread and maintenance. Horseflies (Tabanidae) were particularly singled out as possible vectors of disease. Towards the end of the 1962 clean-up operations, field workers collected numerous insect species from carcasses and sent them south for bacteriological testing. The collection included mosquitoes and deerflies but no horseflies, which had disappeared the week before collection with the arrival of cooler weather. Bacillus anthracis was not isolated from any of the insect species submitted.

\section{DEPOPULATION PROGRAMS}

After the 1964 epizootic, an attempt was made to create a buffer zone in the Grand Detour region. WBNP and CWS officials believed that mixing between bison in the northeast portion of the Park and Hook Lake region occurred only occasionally. They theorized that the spread of anthrax could be contained by a buffer zone between the two groups even though anthrax deaths had already occurred in bison within WBNP itself.

Van Camp and Calef (1987) reported that in the Grand Detour region, 189 bison were slaughtered in November 1964 and 333 in March 1965. However, within a few months a similar number of bison had moved back into the depopulated area. Health of Animals Branch veterinarians were present to inspect both slaughters from the perspectives of meat safety and animal welfare. The field reports of the veterinarians confirm the number of animals killed in the March 1965 hunt, but are at odds on the number of bison culled during the November hunt. One report listed 173 bison slaughtered in November, while a second stated that closer to 250 animals had been killed. In a letter written after both slaughters, Mr. Phillips of the Depart- ment of Northern Affairs and National Resources (NANR) gave an official total of 554 bison for both culls. This final number appears to be the most accurate; however, it is unknown how the total breaks down between the two culls.

Dr. Gallivan reported that NANR personnel also shot bison during the 1971 outbreak in an effort to minimize the risk of its spreading beyond the Hook Lake area. Between 1 and 4 July, at least 44 bison were shot in the region. The carcasses were not processed by clean-up crews but were left on site to be consumed by scavengers.

\section{VACCINATION ROUNDUPS}

An anthrax vaccination program was initiated in the bison herds of Hook Lake and WBNP in 1965 (Carbyn et al., 1993). A Sterne-type live spore vaccine was administered to the animals, using the same dosage and immunization schedule (once a year) as for cattle. Herds of bison were directed with a helicopter into permanent corrals constructed at Hook Lake and at Hay Camp, Lake One, and Sweetgrass Station in the Park. The animals were run through a chute system, where they were branded, vaccinated, and then released. Between 1965 and 1977, a total of 26977 bison were vaccinated against anthrax in northern Canada (Table 2).

While detailed records were kept of the number of bison successfully vaccinated during each roundup, the records

TABLE 2. Bison vaccinations against anthrax at Hook Lake and in Wood Buffalo National Park from 1965 to 1977.

\begin{tabular}{|c|c|c|c|c|}
\hline Date & Location & $\begin{array}{l}\text { Animals } \\
\text { Herded }\end{array}$ & $\begin{array}{c}\text { Animals } \\
\text { Vaccinated }\end{array}$ & $\begin{array}{l}\text { Known } \\
\text { Deaths }^{1}\end{array}$ \\
\hline March 1965 & Sweetgrass & 1623 & 1512 & 18 \\
\hline March 1965 & Hay Camp & - & 249 & (5) \\
\hline May 1965 & Lake One & 2215 & 1441 & 111 \\
\hline May 1965 & Hook Lake & - & 700 & 7 \\
\hline September 1965 & Hay Camp & - & 149 & (3) \\
\hline October 1965 & Hay Camp & - & 109 & (2) \\
\hline 1965 & Sweetgrass & - & 206 & (4) \\
\hline February 1966 & Sweetgrass & 1455 & 1414 & 41 \\
\hline June 1966 & Hook Lake & - & 577 & (12) \\
\hline June 1966 & Lake One & 3587 & 2173 & (72) \\
\hline June 1968 & Sweetgrass & - & 210 & (4) \\
\hline July 1968 & Sweetgrass & - & 744 & (15) \\
\hline July 1969 & Sweetgrass & - & 3021 & $(60)$ \\
\hline February 1970 & Sweetgrass & - & 595 & (12) \\
\hline June 1970 & Sweetgrass & 3921 & 2857 & 44 \\
\hline June 1971 & Sweetgrass & 947 & 779 & 18 \\
\hline June 1972 & Sweetgrass & 5500 & 3612 & 326 \\
\hline June 1972 & Hook Lake & 1154 & 870 & 23 \\
\hline February 1973 & Sweetgrass & 1084 & 1056 & 7 \\
\hline June 1973 & Sweetgrass & 3463 & 2887 & 16 \\
\hline June 1975 & Sweetgrass & 386 & 337 & 3 \\
\hline June 1976 & Sweetgrass & 1110 & 933 & 17 \\
\hline June 1977 & Sweetgrass & 648 & 546 & 8 \\
\hline Total & & $33653^{2}$ & 26977 & $639(828)$ \\
\hline
\end{tabular}

${ }^{1}$ Values in parentheses are extrapolations based on a mean mortality rate of $2.0 \%$.

${ }^{2}$ Where the number of animals herded was unknown, the number of animals vaccinated was used to calculate the total. 
for the total number of animals herded and the number of handling-related mortalities were less complete, especially earlier in the program. As a result, it is difficult to assess the impact of the roundups. The minimum number of animals herded during the roundups was 33653 head, including calves, yearlings, and bison that had already been vaccinated in previous roundups that year. Although these latter groups were not vaccinated, they could not be cut from the herd beforehand and were thus subjected to the same handling procedures and risk of injury as the rest of the herd. The mean mortality rate for roundups during which deaths were observed was $2.0 \%$ of the animals herded. Extrapolating this value to roundups where the number of deaths was not recorded provides an estimated total mortality of 828 animals.

The extrapolation assumes a relatively constant rate of mortality in all roundups. Dr. H.C. Hopf of the HAB indicated in his 1965 field reports that mortality rates differed significantly between the Hook Lake and Lake One corrals, as the latter had a large, boggy area at its entrance where many bison went down and were trampled. He also reported that during some of the roundups, the animals were herded over great distances and arrived at the corrals exhausted, which led to increased mortalities. In 1972, Dr. G.A. Baux of the HAB reported that the mortality rate increased with the number of bison held in the corral. The large number of animals herded during the 1972 Sweetgrass Station roundup resulted in overcrowding in the corral and an elevated mortality rate of $5.9 \%$.

The estimates of roundup-related mortalities take into account only cases that were readily observable by roundup personnel. Wardens believed that only a small portion of roundup-related deaths were actually observed (Carbyn et al., 1993). While physical injuries such as trampling losses and goring wounds could have been rapidly fatal and easily noticed, other deaths, such as those due to exertional myopathies or separation of calves from their dams, could have occurred days later and would not have been detected.

For most of the roundups, the vaccinated bison were branded on the horn or hip for subsequent identification. However, no published data are available on the percentage of bison revaccinated from year to year. Dr. Choquette of the CWS mentioned in a letter to Dr. Lewis that only two $(1.3 \%)$ of the 149 bison vaccinated at Hook Lake in September 1965 had been vaccinated the previous March. Dr. Gould estimated in a field report that approximately half of the 1414 bison vaccinated at Sweetgrass Station in February 1966 were revaccinates, basing his estimate on the presence of a horn-brand. The vaccination program at Hook Lake later that year could identify only $49(8.5 \%)$ of the bison as revaccinates. Identification of the Hook Lake revaccinates was difficult because the animals vaccinated the previous year had been hip-branded: for most animals, this area was still obscured by a thick winter coat that was not yet shed. Overall, the HAB files suggest that, at least for the first few years of the program, the revaccination rate was never greater than $50 \%$.

Personnel involved in the vaccination program stated that it was unlikely that more than one-third of the bison in the areas of the corrals were vaccinated in any given year (Choquette and Broughton, 1967). However, it was felt that the vaccination rate attained would likely prevent a large, explosive outbreak in these areas through herd immunity (Choquette and Broughton, 1967; Choquette, 1970). It is difficult to evaluate the success of the vaccination program. During the years the program was run, only one case of anthrax was recorded in the areas receiving coverage. By the 1971 outbreak, the vaccination program had been scaled back to roundups at Sweetgrass Station only, and animals in the affected Hook Lake region had not been vaccinated for five years (Carbyn et al., 1993). Sterne (1959) noted that whenever any large-scale immunization is undertaken without strict nonimmunized controls, it becomes impossible to prove statistically that a decrease in disease prevalence is due to the immunizations. The bison vaccination program was eliminated in 1977 to counter public criticism of mounting bison losses due to the roundups and to save money on what was perceived to be an ineffective program (Carbyn et al., 1993).

According to the HAB files, at least 1102 bison died of anthrax between 1962 and 1971. Another 283 animals died of anthrax during outbreaks in 1978, 1991, and 1993 (Broughton, 1987, 1992; Carbyn et al., 1993; Gates et al., 1995). A further 598 animals were also killed during depopulation programs in the Grand Detour and Hook Lake regions, and a minimum of 828 animals are estimated to have died during anthrax vaccination roundups. These secondary deaths must also be taken into account in assessing anthrax's impact on the northern bison herds. The final total of 2811 bison mortalities, based on observed carcasses only, is certainly an underestimate of the actual total losses incurred.

It has been over 20 years since anthrax was last observed in the Hook Lake, Grand Detour, and Lake One regions, and it may be tempting to assume that these regions are no longer endemic for the disease. However, all five of the affected areas are remote and experience very little human activity from the end of June to September, when outbreaks have typically occurred (the so-called anthrax season). The Hook Lake and Grand Detour regions have not received systematic surveillance for the disease since the mid-1980s. Today the two regions are subject to a single yearly herd composition study at the beginning of the anthrax season and are unmonitored for the rest of the summer. In contrast, biweekly fire patrol/anthrax surveillance flights are made over the endemic areas in the Park and Sanctuary during the anthrax season. The herds of WBNP have also been the subject of an extensive tuberculosis and brucellosis study for the last three years, during which time they were closely monitored with radio telemetry, and all observed mortalities were investigated. Similarly, in the three years following the outbreak in the 
Sanctuary, its herds were intensely monitored with the help of radio-collars, and all observed carcasses were sampled for anthrax.

Even without apparent outbreaks, it is very likely that $B$. anthracis remains in the regions. The microbe is capable of producing highly resistant spores, which may remain viable and infective for decades in the soil before coming into contact with and infecting a new host. Because of this, all five northern regions must still be considered endemic for the disease, and the resident bison herds remain at risk. Coincidentally, at the time of this writing a road survey crew working in the Park to the west of the Lake One region discovered 12 dead bison. Park wardens collected specimens from the animals to ship south for bacteriological examination and identified ten more carcasses in the general area. To no one's surprise, B. anthracis was isolated from the carcass specimens. By the end of August 2000, the carcasses of 106 bison and 3 moose had been found along the Peace River within the Park.

\section{ACKNOWLEDGEMENTS}

The authors thank the Canadian Food Inspection Agency for allowing us access to the unpublished anthrax files of the Health of Animals Branch. In particular, Dr. Bim Hopf provided a wealth of information on the early anthrax outbreaks, as well as generous advice and counsel in dealing with the 1993 outbreak and subsequent control measures. We are indebted to the many Health of Animals Branch veterinarians whose insightful progress reports have provided us with a better understanding of epidemiology of anthrax in northern Canada. We also thank wardens A. Moreland, J. Mitchell, and C. Wickenheiser of Wood Buffalo National Park for information on the current anthrax outbreak.

\section{REFERENCES}

BROUGHTON, E. 1987. Diseases affecting bison. In: Reynolds, H.W., and Hawley, A.W.L., eds. Bison ecology in relation to agricultural development in the Slave River Lowlands, NWT. Occasional Paper 63. Edmonton, Alberta: Canadian Wildlife Service. 34-38.

1992. Anthrax in bison in Wood Buffalo National Park. Canadian Veterinary Journal 33:134-135.

CARBYN, L.N., OOSENBRUG, S.M., and ANIONS, D.W. 1993.

Wolves, bison... and the dynamics related to the Peace-Athabasca Delta in Canada's Wood Buffalo National Park. Edmonton: Canadian Circumpolar Institute.
CHOQUETTE, L.P.E. 1970. Anthrax. In: Davis, J.W., Karstad, L.H., and Trainer, D.O., eds. Infectious diseases of wild mammals. Ames, Iowa: Iowa State University. 256-266.

CHOQUETTE, L.P.E., and BROUGHTON, E. 1967. Report on the program for the control of anthrax in bison at Wood Buffalo National Park and in the Northwest Territories and on the health status of bison slaughtered in the Park during the fiscal year 1966-67. Unpublished Report CWSC-1108. Ottawa: Canadian Wildlife Service.

CHOQUETTE, L.P.E., BROUGHTON, E., COURIER, A.A., COUSINEAU, J.G., and NOVAKOWSKI, N.S. 1972. Parasites and diseases of bison in Canada. III. Anthrax outbreaks in the last decade in northern Canada and control measures. Canadian Field-Naturalist 86:127-132.

COUSINEAU, J.G., and McCLENAGHAN, R.J. 1965. Anthrax in bison in the Northwest Territories. Canadian Veterinary Journal $6: 22-24$.

DE VOS, V. 1990. The ecology of anthrax in the Kruger National Park, South Africa. In: Turnbull, P.C.B., ed. Proceedings of the International Workshop on Anthrax, Wincester, England, 1113 April 1989. Salisbury Medical Bulletin 68 (Special Supplement):19-23.

DRAGON, D.C., and RENNIE, R.P. 1995. The ecology of anthrax spores: Tough but not invincible. Canadian Veterinary Journal 36:295-301.

GATES, C.C., ELKIN, B.T., and DRAGON, D.C. 1995. Investigation, control and epizootiology of anthrax in a geographically isolated, free-roaming bison population in northern Canada. Canadian Journal of Veterinary Research 59:256-264.

HEATH, K.B., and BREWITT, J.M. 1982. Winter outbreak of anthrax in cattle in Saskatchewan. Canadian Veterinary Journal 23:302-303.

MacEWAN, G. 1995. Buffalo: Sacred and sacrificed. Edmonton: Alberta Sport, Recreation, Parks and Wildlife Foundation.

NOVAKOWSKI, N.S., COUSINEAU, J.G., KOLENOSKY, G.B., WILTON, G.S., and CHOQUETTE, L.P.E. 1963. Parasites and diseases of bison in Canada. II. Anthrax epizooty in the Northwest Territories. In: Transactions of the 28th North American Wildlife and Natural Resources Conference, 4-6 March 1963. 233-239.

PYPER, J.F., and WILLOUGHBY, L. 1964. An anthrax outbreak affecting man and buffalo in the Northwest Territories. Medical Services Journal, Canada 20:531-540.

STERNE, M. 1959. Anthrax. In: Stableforth, A.W., and Galloway, I.A., eds. Infectious diseases of animals: Diseases due to bacteria. New York: Academic Press. 16-52.

VAN CAMP, J., and CALEF, G.W. 1987. Population dynamics of bison. In: Reynolds, H.W., and Hawley, A.W.L., eds. Bison ecology in relation to agricultural development in the Slave River Lowlands, NWT. Occasional Paper 63. Edmonton, Alberta: Canadian Wildlife Service. 21-24. 